\title{
Nutritional status of underfive children of less privileged families in Medan
}

\author{
Indra B Hutagalung, Bangun Lubis, Ridwanto, Hakimi, Endang D Hamid \\ Department of Child Health, Medical School, North Sumatra University-Adam Malik Hospital, Medan
}

\begin{abstract}
A cross sectional study was done on 94 underfive children taken from Keluarga Pra-sejahtera (pre-prosperous family=pre-PF) and Keluarga Sejahtera Tahap-I (prosperous family phase-I=PF-I) in the East Medan subdistrict, municipality of Medan in period of August 1995 up to February 1996. The aim of the study was to measure nutritional status of underfive children in both groups. There were 94 underfive children in group of ore-PF and 94 underfive children in group of PF-1. It was found that the nutritional status of both groups was significantly different. Significant difference was also noted when they were classified according to father's occupational status and father's education level. However when they were grouped according to maternal education, number of children in the family, and occurrence of disease in the previous month no significant difference was detected. [Paediatr Indones 2001;41:11-18]
\end{abstract}

Keywords: underfive children, nutritional status, tess privileged families

\begin{abstract}
A CENSUS OP PROSPEROUS AND PRE-PROSPEROUS FAMLLIES is necessary for the implementation of Act No. 10 of 1992 on the development of population and prosperous family. ${ }^{1.3}$ There are specific indicators to measure the success of national, social, and economic developments, onc of them is the nutritional condition of children, especially underfive. ${ }^{4}$ Nutritional status is an important parameter to monitor a child's growth as well as the health condition of a general population. ${ }^{5}$ From the National Social Economic Survey, or SUSENAS ("Survai Sosial Ekonomi Nasional") in 1992, the actual prevalence of protein calorie malnutrition (PCM) (poor and bad nutritional status) in underfive children was $11.75 \%$ for North Sumatra and $11.80 \%$ for Indonesia in general. The percentage of PCM in North Sumatra was $42.75 \%$ and $41.65 \%$ for
\end{abstract}

Correspondence: Indra B Hutagalung, MD, Department of Child Health, Medical School / Adam Malik Hospital, Jalan Bunga Lau, No. 17 Medan, North Sumatera. Tel. 62-061-8830143. Fax. 62-0618361721 .
Indonesia. ${ }^{6}$ The family census conducted in 1995 indicated that approximatcly $56 \%$ of 39.4 million families in Indonesia still lived in poverty. These families are named pre-prosperous families (pre-PF) and prosperous families phase-I (PF-1). Those PF-1 families have only the means to meet their primary and basic needs such as food, clothes, housc, and health. ${ }^{2}$

The East Medan subdistrict is one of 21 subdistricts in the Municipality of Mcdan. In this subdistrict, there live many pre-PF and PF-I, with a large percentage of underfive children. It is important to detcrmine the nutritional status of these children. Besides food intakc, there are other factors which can influence the nutritional status of underfive children such as genetic factors, acute infection, chronic disease, long-term administration of certain drugs such as corticosteroid, and social economic status of the family. ${ }^{5}$ The aim of this study was to determine the nutritional status of underfive children on both of pre$\mathrm{PF}$ and PF-I in this arca and to compare the results of the two groups. 


\section{Methods}

This cross sectional study was conducted in the East Medan subdistrict, Municipality of Medan from August 1995 to February 1996. The basic data of the poverty index of the families were taken from the subdistrict office. The population was underfive children from pre-PF and PF-1 in East Medan sub. district. Only healthy children 0 to 5 years of age were studied. Families who had moved from the address registered at the subdistrict office, those with an unclear addrcss, or families where the parents of the child did not live at that address were excluded. The total number of subjects was calculated hased on the formula. ${ }^{7}$ With a $95 \%$ confidence interval, the estimated proportion of PF was $43 \%$, and with a significant difference of proportion of $10 \%$, the total subjects calculated for each group was 94 . Subjects were chosen through simple random sampling using a random table. Children and their parents were invited to a village meeting in order to collect data through the use of questionnaires. Body weight and height were measured in accordance with UNICEF recommendation. The weight scale could measure up to 20 $\mathrm{kg}$ with $0.1 \mathrm{~kg}$ accuracy. Body height was mea-sured using a board ruler (for children under 2 ycars) and a microtoise for children who can already stand.

The nutritional status was determined using weight for age (W/A) and height for age (H/A) parameters according to WHO-NCHS Standards and Semiloka Classification (1991):

$$
\begin{array}{ll}
\text { Good } & =\text { W/A or H/A }>-1 \text { SD } \&<+1 \text { SD } \\
\text { Moderate } & =\text { W/A or H/A }>-2 \text { SD } \&<-1 \text { SD } \\
\text { Poor } & =\text { W/A or H/A }>-3 \mathrm{SD} \&<-2 \text { SD } \\
\text { Bad } & =\text { W/A or H/A }<-3 \mathrm{SD}
\end{array}
$$

The prevalence of PCM was determined based on the number of children with poor and bad nutritional status (nutritional status <-2 SD). The whole data were tabulated and presented descriptively. Chi-

TABLE 1. CHARACTERISTICS OF STUDY SUBJECTS

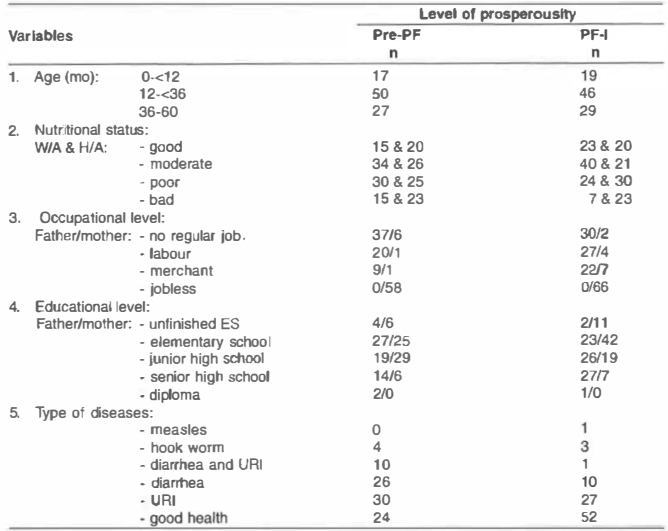

W/A = body weight per age, H/A = body height per age, ES = elementary school,

URI = upper respiratory tract inlection 
TABLE 2. RELATIONSHIP BETWEEN FATHER'S OCCUPATIONAL LEVEL AND NUTAITIONAL STATUS OF PAE-PF AND PF-I UNDERFIVE CHILDREN

\begin{tabular}{llrrrrr}
\hline & Occupational & \multicolumn{5}{c}{ Nutritional status } \\
\cline { 3 - 7 } & level & $\begin{array}{c}\text { good } \\
\mathbf{n}\end{array}$ & $\begin{array}{c}\text { moderate } \\
\mathbf{n}\end{array}$ & $\begin{array}{c}\text { poor } \\
\mathbf{n}\end{array}$ & $\begin{array}{c}\text { bad } \\
\mathbf{n}\end{array}$ & $\mathbf{p}$ \\
\hline Pre.PF & No regular job & 3 & 10 & 16 & 8 & \\
& Labour & 5 & 19 & 10 & 4 & $<0.05$ \\
& Merchant & 7 & 5 & 4 & 3 & \\
PF.1 & No regular job & 11 & 12 & 11 & 5 & \\
& Labour & 3 & 20 & 5 & 1 & $<0.05$ \\
& Merchant & 9 & 8 & 8 & 1 & \\
\hline
\end{tabular}

$p=$ probability

TABLE 3. AELATIONSHIP BETWEEN FATHER'S EDUCATIONAL LEVEL AND NUTRITIONAL STATUS OF UNDERFIVE CHILDREN OF PAE-PF AND PF-I

\begin{tabular}{|c|c|c|c|c|c|c|}
\hline & \multirow{2}{*}{$\begin{array}{l}\text { Educatlonal } \\
\text { level }\end{array}$} & \multicolumn{5}{|c|}{ Nutritional status } \\
\hline & & $\underset{n}{\text { good }}$ & $\begin{array}{c}\text { moderate } \\
\mathbf{n}\end{array}$ & $\begin{array}{c}\text { poor } \\
n\end{array}$ & $\begin{array}{c}\text { bad } \\
\text { n }\end{array}$ & $\mathbf{p}$ \\
\hline \multirow[t]{5}{*}{ Pre-PF } & Unfinished ES & 1 & 0 & 4 & 2 & \\
\hline & Elementary school (ES) & 7 & 13 & 8 & 3 & \\
\hline & Junior high school & 1 & 13 & 13 & 5 & $<0.05$ \\
\hline & Senior high school & 4 & 8 & 5 & 5 & \\
\hline & Diploma & 2 & 0 & 0 & 0 & \\
\hline \multirow[t]{5}{*}{ PF-1 } & Unfinished ES & 0 & 8 & 0 & 1 & \\
\hline & Elementaty school & 6 & 17 & 7 & 1 & \\
\hline & Junior high school & 8 & 3 & 11 & 4 & $<0.05$ \\
\hline & Senior high school & 8 & 12 & 6 & 1 & \\
\hline & Diploma & 1 & 0 & 0 & 0 & \\
\hline
\end{tabular}

squared test using Microstat ${ }^{\mathbb{R}}$ was used to determine the relationship betwcen the two qualitative variables. The significance level of the test was $p<0.05$.

In this study the following definitions were applied: ${ }^{3} \mathrm{~A}$ pre-prosperous family (PF) was defined as a family that had not met any indicators of prosperous family phase-I. A prosperous family phase-I ( $\mathrm{PF}-1)$ was defincd as a family which met the following indicators: (1) The family members ate two or more times a dily; (2) They had different clothes for different situations; (3) They lived on wooden house (not dirt floor); (4) They had a g(x)l health status (sick children were brought to health facilitics).

\section{Results}

There were 94 underfive children of 66 pre-PF and 94 underfive children of 79 PF-I. Must of them were children 12 to 36 months of age. The nutritional status of pre-PF according to W/A was mainly (30 or $32 \%$ ) bad, while the nutritional status for children from PF. I was mostly moderate, i.c. 40 children (43\%). According to $\mathrm{H} / \mathrm{A}, 25$ (27\%) of the pre-PF children had a moderate nutritional status, and $30(32 \%)$ of the children from PF-I had a bad nutritional status. The majority of fathers in both groups did not have a regular job, while the parent's educational level of both groups was mainly elementary school for pre-PF $\&$ senior high school for those of PF-I. The most frequent dis-eases in the previous month were upper respiratory tract infections, followed by diarrhea. See Table 1 .

Table 2 shows that the majority of fathers in both groups did not have a regular job. There were $24(65 \%)$ pre-PF children and $16(41 \%)$ PF-I children who suffercd from PCM. There was a significant association between the father's occupation and the child's nutritional state in both groups $(\mathrm{p}<0.05)$.

Table 3 shows that the majority of father's cducation in both two groups was elcmentary school for 
TABLE 4. RELATIONSHIP BETWEEN MOTHER'S EDUCATIONAL LEVEL AND NUTRIIIONAL STATUS OF UNDER FIVE CHILDREN OF PRE-PF AND PF-I

\begin{tabular}{llccccc}
\hline & Educational & \multicolumn{5}{c}{ Nutritional status } \\
\cline { 2 - 7 } & level & $\begin{array}{c}\text { good } \\
\mathbf{n}\end{array}$ & $\begin{array}{c}\text { moderate } \\
\text { m }\end{array}$ & $\begin{array}{c}\text { poor } \\
\mathbf{n}\end{array}$ & $\begin{array}{c}\text { bad } \\
\mathbf{n}\end{array}$ & P \\
\hline Pre-PF & Unfinished ES & 1 & 2 & 4 & 1 & \\
& Elementary school & $\mathbf{8}$ & 11 & 9 & 2 & $>0.05$ \\
& Junior high school & 8 & 19 & 7 & 3 & $>0.05$ \\
& Senior high school & 6 & 8 & 4 & 1 & \\
PF-I & Unfinished ES & 3 & 1 & 5 & 2 & \\
& Elementary school & 7 & 17 & 15 & 3 & $>0.05$ \\
& Junior high school & 4 & 13 & 8 & 7 & $>0.05$ \\
& Senior high school & 1 & 3 & 2 & 3 & \\
\hline
\end{tabular}

TABLE 5. RELATIONSHIP BETWEEN DISEASE DURING IN THE LAST 1 MONTH AND NUTRITIONAL STATUS OF UNDER FIVE YEARS CHILDREN OF PRE-PF AND PF-I

\begin{tabular}{llrrrrr}
\hline \multirow{2}{*}{$\begin{array}{l}\text { Condition of } \\
\text { children }\end{array}$} & \multicolumn{6}{l}{ Nutritional status } \\
\cline { 3 - 7 } & & $\begin{array}{c}\text { good } \\
\mathbf{n}\end{array}$ & $\begin{array}{c}\text { moderate } \\
\mathbf{n}\end{array}$ & $\begin{array}{c}\text { poor } \\
\mathbf{n}\end{array}$ & $\begin{array}{c}\text { bad } \\
\mathbf{n}\end{array}$ & $\mathbf{p}$ \\
\hline Pre-PF & Sick & 11 & 26 & 20 & 13 & $>0.05$ \\
& Well & 4 & 8 & 10 & 2 & $>0.05$ \\
PF-1 & Sick & 8 & 17 & 11 & 6 & $>0.05$ \\
& Well & 15 & 23 & 13 & 1 & $>0.05$ \\
\hline
\end{tabular}

TABLE 6. RELATIONSHIP BETWEEN NUMBER OF CHILDREN AND NUTRITIONAL STATUS OF PRE-PF AND PF-I

\begin{tabular}{|c|c|c|c|c|c|c|}
\hline & \multirow{2}{*}{$\begin{array}{l}\text { Number of } \\
\text { children }\end{array}$} & \multicolumn{4}{|c|}{ Nutritional status } & \multirow[b]{2}{*}{$p$} \\
\hline & & $\begin{array}{c}\text { good } \\
n\end{array}$ & $\begin{array}{c}\text { moderate } \\
n\end{array}$ & $\begin{array}{c}\text { poor } \\
n\end{array}$ & bad & \\
\hline \multirow[t]{2}{*}{ Pre-PF } & $\leq 2$ & 3 & 13 & 11 & 6 & \\
\hline & $>2$ & 12 & 21 & 19 & 9 & $>0.05$ \\
\hline \multirow[t]{2}{*}{ PF-1 } & $\leq 2$ & 16 & 18 & 11 & 4 & \\
\hline & $>2$ & 7 & 22 & 13 & 3 & $>0.05$ \\
\hline
\end{tabular}

pre-PF and senior high school for PF-I, while $18(56 \%)$ of pre-PF and 8 (26\%) of PF-I children suffered from PCM. There was a significant association between the father's educational level and the child's nutritional state in both groups $(p<0.05)$.

Table 4 shows that the majority of the mother's educational level for both groups was junior high school for pre-PF and elementary school for PF-I. Ten (27\%) of the pre-PFchildren and $15(47 \%)$ of the PFI children suffered from PCM. There was no significant association between mother's educational level and the child's nutritional status in both groups ( $p>0.05)$.
Table 5 shows that $33(47 \%)$ of the pre-PF children and $17(40 \%)$ of the PF-I children who were ill in the previous month suffered from PCM. The data show that there was no significant association between the prevalence of disease in the previous month and the nutritional status of the children in both groups ( $p>0.05$ ).

Table 6 shows that $28(46 \%)$ of the pre-PF children suffered from PCM, while $16(36 \%)$ of the PF-I had more than two children. There was no significant association between the number of children in the family and the nutritional status in both groups $(p>0.05)$. 
TABLE 7. AELATIONSHIP BETWEEN PAOSPEROUSNESS OF FAMILY AND NUTAITIONAL STATUS OF UNDERFIVE CHILDAEN

\begin{tabular}{lccc}
\hline Level of & \multicolumn{2}{l}{ Nutritlonal status } \\
\cline { 2 - 4 } prosperousness & $\begin{array}{ccc}\text { good } \\
\mathbf{n}\end{array}$ & $\begin{array}{c}\text { PCM } \\
\mathbf{n}\end{array}$ & $\mathbf{P}$ \\
\hline pre-PF & 49 & 45 & $<0.05$ \\
PF-1 & 63 & 31 & $<0.05$ \\
\hline
\end{tabular}

TABLE 8. RELATIONSHIP BETWEEN PAOSPEROUSNESS OF FAMILY AND CHILD HEALTH CONDITION IN THE LAST 1 MONTH

\begin{tabular}{lccc}
\hline Level of & \multicolumn{3}{c}{ Condition of children } \\
\cline { 2 - 4 } prosperousity & Slck & Well & p \\
& $\mathbf{n}$ & $\mathbf{n}$ & \\
\hline pre-PF & 70 & 24 & $<0.05$ \\
PF-1 & 42 & 52 & $<0.05$ \\
\hline
\end{tabular}

TABLE 9. AELATIONSHIP BETWEEN CEATAIN CHARACTERISTICS WITH LEVEL OF PROSPEROUSNESS

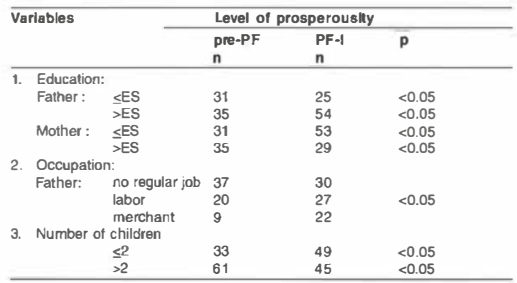

Table 7 shows that 45 (50\%) of the pre-PF children and 31 (33\%) of the PF.I children suffered

PCM. There was a significant association between the family's poverty level and the child's nutritional status $(p<0.05)$. Table 8 shows that $70(74 \%)$ of the prePF children and 42 (45\%) of the PF-1 children suffered from illness in the previous month. There was a significant association between poverty level and the prevalence of disease among the children $(p<0.05)$.

Table 9 shows that the parent's educational level, father's occupation and the number of children in rhe family, each has a significant association with the family's level of poverty $(p<0.05)$.
As much as $95 \%$ of the observed children received breast fecding from their birth up to $4-6$ months, $51 \%$ up to 1 year, and $15 \%$ up to 2 years. Only 4 children of the pre-PF and 6 children of the PF-I received infant formula since birth.

\section{Discussion}

As stated above, a pre-PF is a family that cannot meet their basic needs, such as food. Such condition causes a decrease in the consumption of food, thus causing poor nutritional status. Based on the result of SUSENAS in 1992, there was $42.75 \%$ for PCM (bad 
and poor nutrition status) in North Sumatra and $41.61 \%$ in Indonesia.

In this study, based on $W / \Lambda$, the prevalence of PCM for pre-PF children was $48 \%, 30$ of them (32\%) with poor nutrition and $15(16 \%)$ with a bat nutritional status; and was $48 \%$ for PF-I children, 24 (26\%) with poor nutrition and $7(7 \%)$ with a bad nutritional status, resulting in $40 \%$ as the average rate for both groups. This was higher than the national rate, but it was lower than the results of the study conducted by Simanjuntak in the Sekayam Municipality, West Kalimantan in 1994, with 74\% total prevalence of PEM in poor villages and $52 \%$ in prosperous villages (nutritional status was based on 3 catcgorics of WHO. NCHS. ${ }^{9}$ A study conducted by Lubis in Pakantan village, South Tapanuli, North Sumatra Province (1982) reported $51.6 \%$ of underfive children had a poor nutritional status and $7 \%$ had a bad nutritional status. ${ }^{10}$ Besides that, a study conducted by Tarigan in Nutritional Clinic of Dr. Pirngadi Hospital of Medan (1982) found that $61.3 \%$ of underfive children had a poor nutritional status and $38.7 \%$ had a bad nutritional status (nutritional status was based on KMS card and Harvard standard). ${ }^{11}$

The difference in prevalence was related to the parameter used to determine the nutritional status as well as the basic standard, besides a difference in time. Based on H/A, the prevalence of PCM (poor and bad nutritional status) in this study was $51.06 \%$ for prePF children under the age of five ycars and $56.38 \%$ for $\mathrm{PF}-\mathrm{l}$ children, with an avcrage rate of $53.72 \%$ for the two groups.

This result was higher than result reported by Lubis (1982) and Regar (1982) for children under the age of five in 12 villages in the Province of North Sumatra, which was $39.1 \%$ and $22.9 \%$ respectively. ${ }^{10.12}$ Using a different parameter, a different nutritional status was found. Body weight was an indicator that was used most often to measure nutritional status. Body weight might be quickly depleted by a nutritional disturbance, while recovery quickly improves the nutritional state.

Anthropometry test using body weight could not differentiate between an acutc or chronic malnutrition state, as well as whether malnutrition occurred only in the past. ${ }^{10}$ Most of our subjects, which werc children between 12 to 36 months, also had the highest prevalence of PCM, i.e., 50 (54\%) for the pre-PF group and 46 (45\%) for PF-1. Sitanggang et al reported, $66 \%$ for poor nutrition and $34 \%$ for bad nutritional status was mainly found in the age group of 12.24 month-old children. ${ }^{13}$

It was stated that newborn babies ( 0.1 month) and children ( 1.4 years) had the highest predisposition for poor nutrition. ${ }^{5}$ Such a high prevalence of PEM especially in pre-PF underfivc children with a bad nutritional status was understandable, bearing in mind that they came from the poorest families. In Table 1 , most of the fathers of pre-PF underfive children of age had irregular jobs 37 (56\%) or were manual laborers 20 (30\%). This situation indirectly could influence their income and in turn influence the nutritional status of their children. This was also the casc for the PF-I group $(p<0.05)$ (Table 2). If such job situ. ation was rclated to the level of poverty of the family, the father's job significantly correlates with the prosperity of the family itsclf. It means that with the better job of the father, the more prosperous the family, and finally this situation indirectly influences the nutritional status of their children (Table 1).

In Indonesia, according to SUSENAS data in 1987, bad nutritional prevalence was not only determined by the location of residence, but also to their income rate. ${ }^{4}$

Most ( 27 or $41 \%$ ) of the fathers of the pre-PF graduated from elementary school and the fathers of PF-I mostly graduated from senior high school (27 or $34 \%$ ), while some of them even graduated with a Diploma. On statistical analysis, it was found that father's education of both groups of families significantly correlate with the nutritional status of underfive children $(p<0.05)$ (Table 3). The higher the father's education from both family groups, the better the nutritional status of the children, but this was not the case for the mothers of rhe underfive children $(p>0.05$ ) (Table 4).

In relation with prosperity, the parent's cducation level had a significant association with family prosperity. This means that the better the education of the parent, the more prospcrous the family $(p<0.05)$ (Table 9). Fathers who had a higher education background werc expected to get better jobs, which influences the incomc of the family and finally in turn influcnces the nutritional status of the children. This situation was influenced by the type job the father has (Table 2) 
Table 3 shows that 12 children of the pre-PF group had poor nutritional status and 5 were bad, whilc 7 children of PF-I had poor nutritional status and 2 of them were bad, whilc most of the fathers never finished or just graduated from elementary school. These results were similar to the study conducted by Djoko Kartono and Sihadi (1993), which reflected that the parent's educational level could influence the nutritional status of their children. The higher the parent's level of education, the better nutritional status their children had. ${ }^{14}$ Less food, lower economic status and low lcvel of cducation in the mother could also influcnce food intake, thercfore causing PCM. ${ }^{\text {is }}$

Lubis (1982) reported that most parents who lived in Pakantan village were farmers $(80 \%)$, but he did not reported the relation between job, education level and nutritional status. ${ }^{10}$ Table 6 shows that pre-PF and PF.I children suffered from disease and suffered from discase twice as much in the previous month (70/76\% \& 42/48\%). The duration of the disease was 2-2.5 days and the most common ailment was upper respiratory tract infection (URTI) followed by diarrhea. Based on the SKRT (Survcy Kesehatan Rumah Tangga) in 1992, the prevalence of acute infection was the highest for babies (86\%) and $73 \%$ among underfive children, while diarrhea was $30 \%$ among babies and $20 \%$ among underfive children. ${ }^{16}$

There was a significant relationship between the prospcrity of the family and the prevalence of illncss in children under the age of fivc years in the previous month $(p<0.05)$ (Table 9$)$. The less prosperous the family, the higher the possibility of disease. In this study, the prevalence of illness in children under the age of five years had no relation with nutritional status $(p>0.05)$ (Table 5). This might have happened because of the low level of prosperity in the family. In such a short time of study, most of the children suffercd from acutc illness, so that direct influence of the disease to nutritional status was not so clear.

Referring to the indicator for pre-PF, the capability of this family to mect their needs is very low. Thus, this could indirectly influence predisposition to disease, which finally could influence the nutritional status of their children. Limited food supply and the frequency of infectious diseases were the two of main factors that causes PCM. ${ }^{4}$

The fact says that the usc of breast feeding could prevent malnutrition and diarrhea. ${ }^{17}$ In this study, in general, the observed under five children who were given breast feeding up to $4-6$ th month was $95 \%, 51 \%$ up to 1 year; and $15 \%$ up to 2 years, while 4 underfive children of age from the pre-PF and 6 underfive children of the PF-I only received infant formula, while I of them had bad nutritional status, 2 had poor and 1 had moderate nutritional status. In the same time, from the 6 underfive children from PF-I family who received formula, 2 of them had bad nutritional status. The mothers of these children mostly wcre not able to breast-feed.

According to SKRT (1992), 63.7\% children reccived brcast-feeding up to 3 months and $32.5 \%$ up to 11 months. ${ }^{16}$ Babies who reccived formula suffered from PCM more frequently than those who were breastfed because the more diluted milk could cause diarrhca. Poor families often gave diluted milk to their babies. ${ }^{18}$

According to the family planning program, an idcal family consists of a father, mother and two children. In this study, children from families with more than 2 children, both from the PF-I or pre-PF groups, had a higher prevalence of PCM than those in families with two children or less. Statistic analysis showed that there was no significant association bctween number of children to the nutritional status of underfive children, but it was related with level of poverty of the family $(p<0.05)$ (Table 9$)$, where rhe smaller the number of children $(<2)$, the family was expected to be more prosperous, which would indirectly influence the nutritional status of the children.

A study conducted by Lubis found that the larger the number of children in a family, the more the underfive children would suffer from malnutrition. ${ }^{10}$ From the result of this study, based on W/A, the nutritional status of underfive children from PF.I was better than for pre-PF $(p<0.05)$. Based on $H / A$, as a matter of fact, PCM in children under the age of fivc years in the PF-I group was higher than for pre-PF. This shows that PCM happened a long time, perhaps more than 1 ycar. The morc prosperous the family, the better the nutritional status of the underfive children. (Table 7).

Statistical analysis showed that educational levcl, type of job, illness in the previous month, number of children in a family and the nutritional status of underfive children did not always have a direct rclationship. It might be caused by the fact that this 
group came from very poor familics. Thus, we tried to find relationships among the various variables to the level of prosperity of the family, which indirectly influences long term nutritional status. In fact, there was a significant rclationship between those variables (Table 9). Thus, prosperous family phases made by BKKBN (Badan Koordinasi Keluarga Berencana Nasional) have a very importance role in child health.

In summary, we have found that the prevalence of PCM in these family groups was still high, especially for the pre.PF. A significant association was found between the father's type of job and cducation level to the nutritional status of the underfive children. However, there was no significant association between the mother's educational level and the children's nutritional status. The number of children in the family also did not show any significant association. There was a significant association between the father's education levels, type of job, and number of children in the family with the level of poverty of the family.

Even though a direct cause between the father's job, educational level \& prevalence of illness in the previous month and the nutritional status could not be proven, there was a clear relationship. The level of poverty might have an influence in causing diseases that finally influence nutritional status. This is an initial study of these families groups, and further ob. servation in the same field conducted in other places is needed for comparison to support government programs even further.

\section{References}

1. Semiloka Antropometri. Hasil dan rekomendasi Semiloka Antropometridi Indoncsia, Ciloto, 3-7 February 1991.

2. BKKBN. Panduan pembangunan keluarga sejahtera dalam rangka peningkatan penanggulangan kemiskinan. Kantor MenteriNegara Kependudukan/BKKBN, Jakarta 1997.
3. BKKBN. Petunjuk teknis pendataan dan pemetaan keluarga sejahtera: BKKBN. Gerakan keluarga berencana nasional. Cetakan I, Jakarta 1993.

4. Jalal F, Soekirman. Pemanfaatan antropometri sebagai indikatorsusial ekonumi. Gizilndonesia 1990; 14(2):26-36.

5. Nazar SS, Sudibyo S. Gangguan gizi. In:buku ajar Ilmu Kesehatan Anak FKUI, Jakarta 1991; 1:163-4.

6. Info pangan dan gizi. Edisi khusus siruasi masalah dan program gizi sampai dengan akhir Pelita V. Jaringan infonnasi pangan dangiziDepartemen KesehatanRI 1993; IV:1-8.

7. BPS. Mantristatistik Kecamatan Medan Timur, Kotamadya Medan dalam angka tahun 1995.

8. World Health Organization. Measuring change in nutritional status. Guidelines for assessing the nutritional impact of supplementary feeding programmness for furnerable groups. W/HO:Geneva, 1983.

9. Simanjuntak G. Status gizi balita di Kecamatan Sekayam Propinsi Kalimantan Barat. Medika 1996; 3:205-6.

10. Lubis IZ, Nurbafri NY, Nasution MA, Tarigan S, Lubis CP. Keadaan gizi balita didesa Pakan, Tapanuli Selatan. Presented at KONIKA V1 1984, Denpasar.

11. Tarigan S. Penyebab dan follow-up anak dengan gizi kurang. Presented at KONIKA IV 1987, Yogyakarta.

12. Siregar $\mathrm{H}$. Tinjauan kesehatan anak di beberapa pedesaan di Sumatera Utara. Pidato pengukuhan dan peresmian jabatan guru besar tetap, Medan 4 Juni 1993

13 Sitanggang RS, Dharmawati C, Nasution R, Hamid $\mathrm{ED}$, Tarigan $\mathrm{S}$. Factors influencing malnutrition in children at the out patient clinic of the Pediatric Nutrition subdivision, PimgadiHospital Medan 1985-1989. Paediatr Indones 1993; 33:1-8.

14 Sihadi, Kartono D. Beberapa aspck psikososial pada anak kurang energi protein (KEP) di daerah Bogor. Penclitian Gizi Makanan 1993;16:8-15.

15. Pudjiati S. Ilmugizi klinis pada anak, edisi pertama, Jakarta, Balai penerbit FKUI 1990; 93-119.

16. SKRT: Badan Penelitian dan Pengembangan Kesehatan Departemen Kesehatan 1992; 45-55.

17. Sri Duryati, Suharyono. Manfaat ASI dan tumbuh kembang anak. In:Kesehatan ibu dan keluarga berencana. Majalah Kedokteran Indonesia 1991; 41 (8):474-80.

18. UNICEF. Nutrition. In: Unicef annual report 1994:50-5. 